\title{
Early Administration of Peroxisomicine A1 (T-514 Extracted from $K$. parvifolia Seeds) Causes Necrosis of Implanted TC-1 Cells without Affecting Target Organs in a Murine Model
}

\author{
La Administración Temprana de Peroxisomicina A1 (T-514 Extraída de las semillas de K. parvifolia) \\ Causa Necrosis de Células TC-1 Implantadas sin Afectar Órganos Blanco en un Modelo Murino \\ *Adolfo Soto-Domínguez; ${ }^{* * \dagger}$ Alfredo Piñeyro-López; *****Odila Saucedo-Cárdenas; \\ ***** Rosalba Ramírez-Durónd; **** Noemí Waksman de Torres \& *Julio Sepúlveda-Saavedra
}

SOTO-DOMÍNGUEZ, A.; PIÑEYRO-LÓPEZ, A.; SAUCEDO-CÁRDENAS, O.; RAMÍREZ-DURÓN, R.; WAKSMAN DE TORRES, N. \& SEPÚLVEDA-SAAVEDRA, J. Early administration of peroxisomicine A1 (T-514 extracted from K. parvifolia Seeds) causes necrosis of implanted TC-1 cells without affecting target organs in a murine model. Int. J. Morphol., 30(1):284-289, 2012.

SUMMARY: Peroxisomicine A1 (PA1), one of the toxins isolated from seeds of plants of the Karwinskia genus, whose targets organs are the liver, kidney, and lungs. There is a selective toxicity in vitro to cancer-cell lines derived from the lungs, liver, and colon, compared to normal cell lines. PA1 caused apoptosis in several cancer-cell lines in culture. In toxic doses to rodents, it causes extensive apoptosis in the liver, kidney, and lungs. In our study we were interested in evaluating, for the first time, the morphological effects of administration of PA1 to implanted TC-1 cells and in the target organs in vivo. The TC-1 cells were cultured and injected into the hind limb of C57BL-6 mice. The animals were divided into 3 groups; those treated with four doses of $1 \mathrm{mg} / \mathrm{kg}$ each of PA1, the untreated control, and the vehicle-control groups. All mice were killed 10 days after cell implantation. Samples were obtained from TC-1 cells at the implantation site and from the liver, kidney, and lungs. The samples were processed for examination under light and electron microscopy. In the PA1-treated group, the TC-1 cells had necrosis, whereas in the control groups the tumor cells were undamaged. The target organs did not show any lesions. We demonstrated for the first time that there is a selective toxic effect of PA1 on the TC-1 cells in vivo.

KEY WORDS: Antineoplasic effect; Necrosis; Peroxisomicine A1; Selective toxicity; TC-1 cells.

\section{INTRODUCTION}

Peroxisomicine A1 (PA1) or toxin T-514 is a dimeric anthracenone isolated from the endocarp of plants of the Karwinskia genus. It belongs to the group of toxic compounds identified by Dreyer et al. (1975) in these plants, and named according to their molecular weight as T-496, T-514, T-516, and T-544. Bermudez et al. (1986) reported that in rodents the target organs for T-514 are the lungs, liver, and kidney. Piñeyro et al. (1994) described for the first time the presence of the selective toxicity of T-514 on human cancer-cell lines derived from the liver, lungs, and colon compared to their normal counterparts. In the same study they compared the selective toxicity of several known cytotoxic drugs (vincristine, epidoxorubicine, and 5-fluoracil) with the effect of T-514. They noted that normal cells were more sensitive to the effect of the tested drugs than tumor cells, whereas tumor cells were more sensitive to T-514 than normal cells. These findings led them to carry out further experiments to suggest T-514 as a potential antineoplasic drug. Piñeyro $(1995 ; 1996)$ obtained a patent for the use of T-514 as a potential antineoplasic agent from the European Economic Community, USA, Japan, Korea, Canada, and Mexico.

Preliminary data about the mechanism of action of T-514 indicates that the peroxisome is the target organelle in yeast (Sepúlveda-Saavedra et al., 1992) and in rodents (Moreno-Sepulveda et al., 1997, SepúlvedaSaavedra et al., 1998). For this reason the compound was renamed peroxisomicine.

\footnotetext{
Departamento de Histología, Facultad de Medicina, Universidad Autónoma de Nuevo León, México.

** IPharma, S.A. Monterrey, N.L. México.

**** Centro de Investigación Biomédica del Noreste, IMSS, Monterrey, N.L., México.

***** Departamento de Química Analítica, Facultad de Medicina, Universidad Autónoma de Nuevo León, México.
} 
SOTO-DOMÍNGUEZ, A.; PIÑEYRO-LÓPEZ, A.; SAUCEDO-CÁRDENAS, O.; RAMÍREZ-DURÓN, R.; WAKSMAN DE TORRES, N. \& SEPÚLVEDA-SAAVEDRA, J. Early administration of peroxisomicine A1 (T-514 extracted from K. parvifolia Seeds) causes necrosis of implanted TC-1 cells without affecting target organs in a murine model. Int. J. Morphol., 30(1):284-289, 2012.

Lansiaux et al. (2001) reported the presence of apoptosis caused by T-514 in human leukemia cells in vitro. Martínez et al. (2001) demonstrated the presence of apoptosis in several transformed cell lines in vitro when treated with PA1, such as HeLa, mammary, colon adenocarcinoma, and hepatoma cell lines. When given to normal nontumor-bearing mice in high toxic doses (28 mg PA1/kg body weight) vs $1 \mathrm{mg}$ PA1/kg body weight given in our study, T-514 caused extensive apoptosis in the target organs, liver, kidney, and lungs (Soto-Domínguez et al., 2005). Preliminary results showed that mice treated with PA1 had a decrease in tumor growth compared to the control groups and an increase in survival time, which studies were made in our laboratory. The purpose of our study was to evaluate the morphological effect of an early administration of low doses of T-514, ten days post-implantation of TC-1 cells when no tumor can yet be detected, and to compare this with the effects in the liver, kidney, and lungs.

\section{MATERIAL AND METHOD}

Tumor cell-line TC-1. The TC-1 cell-line was obtained from ATCC (CRL-2785) (Manassas, VA, USA). According to Lin et al. (1996) this cell line was derived from a primary culture of epithelial cells of the mouse strain C57BL-6 (Lin et al.). When these cells are implanted in the C57BL-6 mice, there is no immunological rejection and these mice were then successfully used as a model of murine cancer (Lin et al.; Greenstone et al., 1998; Tuve et al. 2007).

Cell-culture techniques and cell implantation. Cells were cultured in Dulbecco's modified Eagle Medium-1 supplemented with $10 \%$ fetal bovine serum, incubated at $37^{\circ} \mathrm{C}$ in $5 \% \mathrm{CO}_{2}$ and $95 \%$ humidity. At confluence, the cells were harvested with $0.25 \%$ trypsin. The cell suspension was maintained in ice, washed with phosphate saline buffer (PBS), $\mathrm{pH} 7.2$ - 7.4. The cells were adjusted to a final concentration of $5 \times 10^{4} / 100 \mathrm{~mL}$ of PBS. This amount was implanted in the subcutaneous tissue of the hind limb of male mice strain C57BL-6, weighing 25 to $30 \mathrm{~g}$ (Harlan, Mexico). Before and after injection, cell viability was determined with trypan blue yielding a value of $>95 \%$ viability. The animals were kept under standard laboratory conditions of temperature 22 to $25^{\circ} \mathrm{C}, 65 \%$ to $70 \%$ humidity, fed with a standard diet and water ad libitum, with 12-h lightdark cycles in the animal facilities of the Histology Department, Facultad de Medicina, UANL.

Peroxisomicine A1. PA1 (toxin T-514) was purified and identified by Ramírez-Durón and Waksman de Torres from fruits of $K$. parvifolia using procedures already described (Osorio-Perez et al., 2003; Fernández-Ramírez et al., 2004).
Experimental groups. Eighteen mice strain C57BL-6 were used and divided into three experimental groups; the PA1treated group $(n=6)$, a vehicle-control group $(n=6)$, and an untreated-control group $(n=6)$. All animals received a subcutaneous injection of a 5 x 104 TC-1-cell suspension into the hind leg. The day of the injection was day 0 . The PA1-treated group received, 4 doses of $1 \mathrm{mg} / \mathrm{kg}$ body weight of PA1 in carthamus oil ip, on days $2,4,6$, and 8 postimplantation. The vehicle-control group received only carthamus oil on the same days, last group received no treatment (absolute control).

Tissue collection. To evaluate the morphological effects, samples were collected at day 10 after cell implantation, at which time no tumor was present. All animals were killed by cervical dislocation. Tissue samples were collected from the hind leg at the site of the cell implantation and from the lungs, liver, and kidney.

Morphological analysis. All mice were perfused through the left ventricle with a fixative solution of $0.25 \%$ glutaraldehyde in cacodylate buffer, $\mathrm{pH} 7.2$ to 7.4, samples were collected and further processed either for light microscopy or for electron microscopy.

Light microscopy. The samples were fixed in a freshly prepared solution of $4 \%$ paraformaldehyde dissolved in PBS, processed by routine histological techniques, and embedded in paraffin. Five-micron sections were obtained, mounted, and stained with the hematoxylin-eosin technique or with the Masson trichromic-method (Masson, 1929).

Electron microscopy. Samples were quickly removed and placed in a drop of fixative, minced, and then transferred to a vial containing $4 \%$ paraformaldehyde, $5 \%$ glutaraldehyde, and $0.05 \%$ picric acid in $0.1 \mathrm{M}$ PBS (Ito \& Karnovsky, 1968). After one hour the tissues were rinsed briefly in buffer and postfixed in $2 \%$ aqueous osmium tetroxide for one hour at room temperature. The tissues were then treated with a $1 \%$ aqueous solution of uranyl nitrate. After rapid dehydration with ethanol, the tissues were embedded in epoxy resin using the technique of Luft (1961). Sectioning was done with a diamond knife on an RMC ultramicrotome. The sections were collected on 200-mesh copper grids without a supportive substrate, stained with uranyl acetate (Watson, 1958), and then by lead citrate (Venable \& Coggeshall, 1965). Microscopy was done in a Carl Zeiss EM10 electron microscope. One-micron sections were mounted on glass slides and stained with $1 \%$ toluidine blue for study with the light microscope.

TUNEL test for the demonstration of chromatin fragmentation. For the TUNEL test (Gavrieli et al., 1992) 
SOTO-DOMÍNGUEZ, A.; PIÑEYRO-LÓPEZ, A.; SAUCEDO-CÁRDENAS, O.; RAMÍREZ-DURÓN, R.; WAKSMAN DE TORRES, N. \& SEPÚLVEDA-SAAVEDRA, J. Early administration of peroxisomicine A1 (T-514 extracted from K. parvifolia Seeds) causes necrosis of implanted TC-1 cells without affecting target organs in a murine model. Int. J. Morphol., 30(1):284-289, 2012.

the kit, TACS 2TdT in situ Apoptosis Detection, Trevigen, was used. The kit instructions were followed and samples were analyzed by light microscopy.

Immunohistochemistry and quantitative analysis of identified cell populations. For cell identification, specific monoclonal antibodies (Dako Cytomation, Inc.) were used to identify T-lymphocytes anti-CD3+, B-lymphocyte antiCD20+, macrophage anti-CD15+, and NK cell anti-CD56+. The procedures were done using the kit instructions. After identification of infiltrating cell types, positive cells for each marker were counted in three slides (one for each mouse) of each group. Briefly, a first field was selected at random with the oil immersion objective $(100 \mathrm{X})$ and in the eight consecutive fields cells were counted. The total number of cell types was counted. The percentage of positive cells was calculated and an average value was obtained, as was the standard deviation and standard error for each group. Data were graphed and a statistical Student's t-test was used with a degree of significance of $\mathrm{P}<0.05$.

\section{RESULTS}
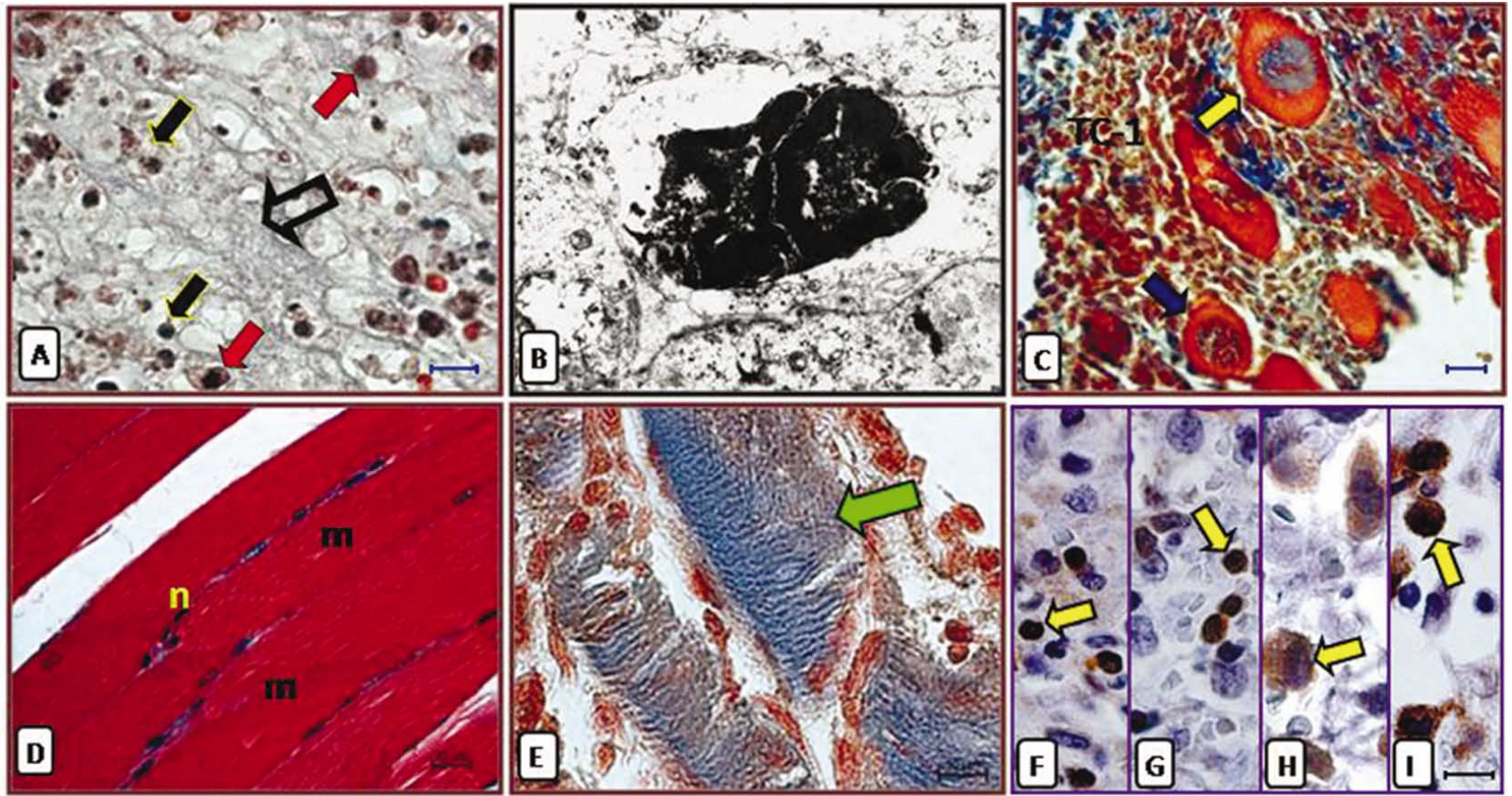

Fig. 1. A) TC-1 cells at the implantation site, PA1 treated. Light micrograph: cell necrosis (empty arrow), pyknotic nuclei (black arrows), and mononuclear cells (red arrows). Paraffin embedded, Masson staining. 10- $\mu \mathrm{m}$ bar. B) TC-1 cells at the implantation site, PA1 treated. Electron micrograph. Cell with signs of necrosis, observe pyknotic nuclei. 10,000 x. C) TC-1 cells at the implantation site, Untreated group. Light micrograph: TC-1 cells (TC-1), skeletal muscle fibers with nucleus in a central location (blue arrow). Fibers with change in staining pattern (yellow arrow). Paraffin embedded. Masson stain. 20- $\mu \mathrm{m}$ bar. D) Normal skeletal muscle cells (m) stained with Masson technique, observe bright red color, peripheral nuclei (n). Paraffin embedded. Masson stain. 20- $\mu \mathrm{m}$ bar. E) TC-1 cells at the implantation site, untreated group. Light micrograph: The micrograph shows the color variation in skeletal muscle fibers (green arrow). Paraffin embedded. Masson stain. 10- $\mu \mathrm{m}$ bar. F, G, H, I) TC-1 cells at the implantation site, PA1 treated. Light micrograph. Observe positive cells 
SOTO-DOMÍNGUEZ, A.; PIÑEYRO-LÓPEZ, A.; SAUCEDO-CÁRDENAS, O.; RAMÍREZ-DURÓN, R.; WAKSMAN DE TORRES, N. \& SEPÚLVEDA-SAAVEDRA, J. Early administration of peroxisomicine A1 (T-514 extracted from K. parvifolia Seeds) causes necrosis of implanted TC-1 cells without affecting target organs in a murine model. Int. J. Morphol., 30(1):284-289, 2012.

The cell types identified were T-lymphocytes CD3+ (Fig. 1F), B-lymphocytes CD20+ (Fig. 1G), macrophages CD15+ (Fig. 1H), and NK cells CD56+ (Fig. 1I).

Morphological observations of target organs. All samples from the liver, lungs, and kidney, including that treated with PA1, showed normal histological features. No signs of toxicity were seen in the treated animals. These features were confirmed by using the electron microscope, where no abnormal signs were observed in any sample of the target organs, either treated with PA1 or untreated (Figs. 2A to 2F).

TUNEL technique. The TUNEL reaction was negative for chromatin fragmentation in all samples evaluated (Figs. 2G to I).

Infiltrating cell quantification. Cell counts for each identified cell type and experimental group demonstrated the presence of a pattern in which the largest percentage of infiltrating cells was T-lymphocytes $(17.3 \% \pm 0.4 \%)$ in all groups. Macrophages $(13.0 \% \pm 0.3 \%)$ were the second most abundant cells, then B-lymphocytes (10.8\% $\pm 0.4 \%)$, with the least frequent NK cells $(10.3 \% \pm 0.3 \%)$. The amounts of the infiltrating cells present in each group did not show differences among groups, either treated with PA1 or untreated (Fig. 3).

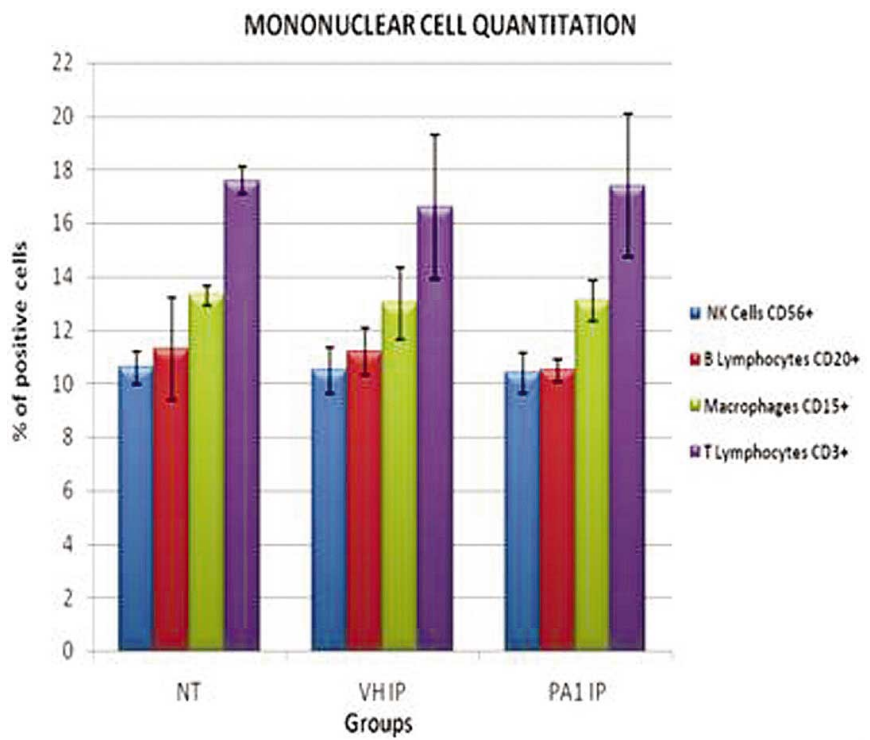

Fig. 3A) Graphic of quantization of mononuclear cells. Cell counts for each identified cell type and experimental group demonstrates the presence of a pattern where the largest percentage of infiltrating cells is T-lymphocytes in all groups. Macrophages were the second most abundant cells, and then B-lymphocytes, with the least frequent the NK cells. Amounts of the infiltrating cells present in each group did not show differences among groups, either treated or untreated with PA1
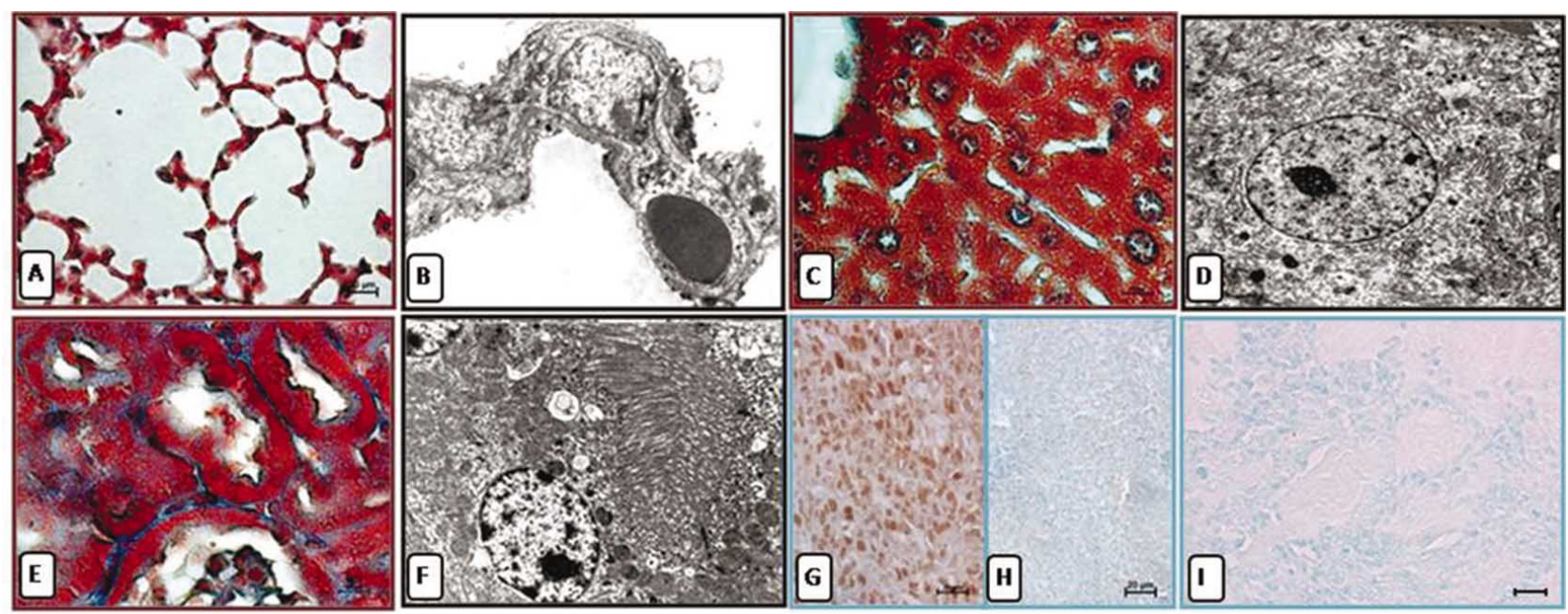

Fig. 2. A) Lung, PA1 treated. Light micrograph: Normal histological image. Paraffin embedded, Masson staining. 20- $\mu \mathrm{m}$ bar. B) Lung, PA1 treated. Electron micrograph: Observe normal appearance. 3,150x. C) Liver, PA1 treated. Light micrograph: Observe normal histology. Paraffin embedded, Masson staining. 20- $\mu \mathrm{m}$ bar. D) Liver, PA1 treated. Electron micrograph: No lesions are present. 6,150x. E) Kidney, PA1 treated. Light micrograph: Observe normal histology. Paraffin embedded, Masson staining. 20- $\mu \mathrm{m}$ bar. F) Kidney, PA1 treated. Electron micrograph: No lesions are present. 6,150x. G) TUNEL Positive control. Tumor mass. Untreated group. Light micrograph: observe brown staining in positive nuclei. Paraffin embedded. TUNEL. 20- $\mu \mathrm{m}$ bar. H) TUNEL Negative control. Tumor mass. Untreated group. Light micrograph: observe negative nuclei. Paraffin embedded. TUNEL. $20-\mu \mathrm{m}$ bar. I) TC-1 cells from the implantation cell site, PA1 treated mice. Light micrograph: Negative nuclei for chromatin fragmentation. Paraffin embedded. TUNEL. 20- $\mu$ m bar 
SOTO-DOMÍNGUEZ, A.; PIÑEYRO-LÓPEZ, A.; SAUCEDO-CÁRDENAS, O.; RAMÍREZ-DURÓN, R.; WAKSMAN DE TORRES, N. \& SEPÚLVEDA-SAAVEDRA, J. Early administration

of peroxisomicine A1 (T-514 extracted from K. parvifolia Seeds) causes necrosis of implanted TC-1 cells without affecting target organs in a murine model. Int. J. Morphol., 30(1):284-289, 2012.

\section{DISCUSSION}

The results of our study demonstrate for the first time that there is a selective toxicity in vivo of PA1 on the TC-1 cells implanted into mice, because they show necrosis whereas the target organs, the lungs, liver, and kidney, do not show any lesions.

The histological and ultrastructural study of the TC1 cells showed the presence of signs indicative of necrosis; cell membrane rupture, cytoplasm extraction, loss of organelles, and pyknotic nuclei. No morphological signs indicative of apoptosis were present, such as apoptotic bodies or characteristic chromatin condensation. The TUNEL technique to demonstrate chromatin fragmentation was negative in all samples tested, except in the positive-test control slides treated with nuclease. These findings are different from those reported in other studies made on leukemia cells (Lansiaux et al.), where they reported a dosedependent apoptosis caused by PA1. There is also a report of apoptosis caused in HeLa cells, and in mammary adenocarcinoma, colon adenocarcinoma, and hepatoma (Martínez et al.). The differences in the results reported in vitro, compared with the study in vivo reported here, could be caused by the concentration of PA1 reaching the cells, which could be greater in the system in vitro than in the model in vivo. In the report of Lansiaux et al. the low concentrations of PA1 did not cause apoptosis, whereas in normal nonbearing-tumor mice intoxicated with high doses of PA1 (28 mg of PA1/kg body weight) extensive apoptosis is present in the liver, kidney, and lungs (Soto-Dominguez et al.). The actual mechanism behind the different sensitivity among normal and tumor cells to PA1 is unknown.
For the types of lymphoid cells present, we observed the same pattern in each sample evaluated, both treated and untreated with PA1. This indicates that PA1 is not related to the presence of these cells, rather their presence could be caused by the recognition of membrane antigens present in the TC-1 cells, namely the oncoproteins E6 and E7 of the Human Papilloma Virus-16 (Lin et al.). The lymphoid cell counts demonstrate that there is a predominance of $\mathrm{T}$ lymphocytes in all groups, followed by macrophages, B lymphocytes, and NK cells, suggesting a cellular immuneresponse directed against cell antigens.

The target organs did not show any toxic effect, which correlates with the findings obtained in the doses-response graph, showing that mortality begins when $10 \mathrm{mg}$ of PA1/ body weight are administered. Thus, it is likely that larger doses of PA 1 could be administered to improve the beneficial results found in this study. It is feasible to increase the dose as long as no toxic effects are detected in the target organs. Further experiments are being made in our laboratory to test this possibility, to determine if treated tumor-bearing mice show a longer survival time when treated with PA1, and to evaluate the rate of tumor growth in treated $v s$ untreated mice. Preliminary observations obtained by our group indicate that this true.

\section{ACKNOWLEDGMENTS:}

We are grateful to PAICYT 2006 SA1464-06 for financial support of the present investigation and to CONACYT for scholarship 42018. For technical assistance to Nora Frías, Rosa Ma. Leal, Enrique Ramírez, Patricia Flores, Silvia M. García and Esaú García. Thanks to Dr. Ellis Glazier for editing the English-language text.

SOTO-DOMÍNGUEZ, A.; PIÑEYRO-LÓPEZ, A.; SAUCEDO-CÁRDENAS, O.; RAMÍREZ-DURÓN, R.; WAKSMAN DE TORRES, N. \& SEPÚLVEDA-SAAVEDRA, J. La administración temprana de peroxisomicina A1 (T-514 extraída de las semillas de $K$. parvifolia) causa necrosis de células TC-1 implantadas sin afectar órganos blanco en un modelo murino. Int. J. Morphol., 30(1):284-289, 2012.

RESUMEN: Peroxisomicina A1 (PA1), una de las toxinas aisladas de las semillas de plantas del género Karwinskia, cuyos órganos blanco son hígado, riñón y pulmón. Hay una toxicidad selectiva in vitro contra líneas celulares cancerosas derivadas de pulmón, hígado y colon, comparadas con líneas celulares normales. PA1 causa apoptosis en varias líneas celulares malignas en cultivo. En dosis tóxicas a roedores, causa extensa apoptosis en hígado, riñón y pulmón. En nuestro estudio, estuvimos interesados en evaluar por primera vez los efectos morfológicos de la administración temprana de PA1 sobre células TC-1 implantadas y los órganos blanco in vivo. Las células TC-1 fueron cultivadas e implantadas en la extremidad posterior de ratones C57BL-6. Los animales fueron divididos en tres grupos: tratado con cuatro dosis de $1 \mathrm{mg} / \mathrm{kg}$ de peso de PA1, control sin tratamiento y control vehículo. Todos los animales fueron sacrificados 10 días posterior al implante de las células. Se colectaron muestras del sitio del implante de las células TC-1 y de hígado, riñón y pulmón. Las muestras fueron procesadas para su análisis a microscopía de luz y microscopia electrónica de transmisión. En el grupo tratado con PA1, las células TC-1 presentaron necrosis, mientras que en los grupos control las células tumorales se observaron sin daño. Los órganos blanco no mostraron lesión alguna. Demostramos por primera vez que existe un efecto tóxico selectivo de PA1 sobre las células TC-1 in vivo.

PALABRAS CLAVE: Efecto antineoplásico; Necrosis; Peroxisomicina A1; Toxicidad selectiva; células TC-1. 


\section{REFERENCES}

Bermudez, M. V.; Gonzalez-Spencer, D.; Guerrero, M.; Waksman, N. $\&$ Piñeyro A. Experimental intoxication with fruit and purified toxins of buckthorn (Karwinskia humboldtiana). Toxicon, 24:1091$7,1986$.

Dreyer, D. L.; Arai, I.; Bachman, C. D.; Anderson, W. R.; Smith, R. G. \& Daves G.DToxins causing no inflammatory paralytic neuronopathy. Isolation and structure elucidation. J. Am. Chem. Soc., 97:4895-990, 1975

Fernández-Ramírez, A.; Salazar-Cavazos, M. L.; Rivas-Galindo, V.; Ceniceros-Almaguer, L. \& Waksman de Torres, N. Determination of Isoperoxisomicine A1 contents in Peroxisomicine A1 batches by mean of 1H NMR. Anal. Lett., 37(12):2433-44, 2004.

Gavrieli, Y.; Sherman, Y. \& Ben-Sasson, S. A. Identification of programmed cell death in situ via specific labeling of nuclear DNA fragmentation. J. Cell Biol., 119(3):493-501, 1992.

Greenstone, H. L.; Nieland, J. D.; de Visser, K. E.; De Bruijn, M. L.; Kirnbauer, R.; Roden,R. B.; Lowy, D. R.; Kast, W. M. \& Schiller J. T. Chimeric papillomavirus virus-like particles elicit antitumor immunity against the E7 oncoprotein in anHPV16 tumor model. Proc. Natl. Acad. Sci. USA, 95:1800-5, 1998.

Ito, S. \& Karnowsky M. Formaldehyde-glutaraldehyde fixative containing trinitro compounds, J. Cell. Biol., 39:168a-9a, 1968.

Lansiaux, A.; Laine, W.; Baldeyrou, B.; Mahieu, C.; Wattez, N.; Vezin, H.; Martinez, F.; Piñeyro, A. \& Bailly C. DNA topoisomerase II Inhibition by peroxisomicine A (1) and its radical metabolite induces apoptotic cell death of HL-60/MX2 human leukaemia cells. Chem. Res. Toxicol., 14(1):16-24, 2001.

Lin, K. Y.; Guarnieri, F. G.; Staveley-O’Carroll, K. F.; Levistky, H. I.; August, T.; Pardoll, D. M. \& Wu, T. C. Treatment of established tumors with a novel vaccine that enhances major histocompatibility class II presentation of tumor antigen. Cancer Res., 56:21-6, 1996.

Luft, J. Improvements in epoxy resins. Embedding methods. J. Biophys. Biochem. Cytol., 9:409-14, 1961.

Martinez, F. J.; Zeng, G.; Piñeyro, A.; Garza-Ocañas, L.; Tomei, D. \& Umansky S. Apoptosis induction and cell cycle perturbation is established cell lines by Peroxisomicine A1 (T 514). Drug Chem. Toxicol., 24 (3):287-99, 2001.

Masson, P. J. Trichrome staining and their preliminary techniques. J Tech. Met. Armed Forces Institute of Pathology. AFIP, Washington DC, USA, 12-75. 1929. Cited in: Garro, M. L.; Barbeito, C.; Mario, R. C.; Galarza, B. C. \& Cantera, C. S. Evaluación histológica del efecto de enzimas con actividad depilatoria sobre piel vacuna. Un estudio preliminar. InVet., 8(1):103-10, 2008.

Moreno-Sepúlveda, M.; Vargas-Zapata, R.; Ballesteros-Elizondo, R.; Piñeyro-López, A. \& Sepúlveda-Saavedra, J. Studies on the effect of peroxisomicine on catalase activity in albino mice. Toxicon, 35:777-83, 1997.
Osorio-Pérez, A.; Salazar-Cavazos, M.; Pineyro-López, A. \& Waksman de Torres, N. Optimization and validation of an analytical procedure by high-performance liquid chromatography for the quantification of peroxisomicines and isoperoxisomicines. J. Chromatogr. B Analyt. Technol. Biomed. Life Sci., 783(1):85-92, 2003.

Piñeyro, A. European Patentblatt 95/48 (29.11.95) Patent number: 0467407, 1995.

Piñeyro A. Bioscience patent "Pharmaceutically acceptable anthracene compounds number 5578646. Japanese patent number 2651758, Korean patent number 202320. Canadian patent number 2047550, Mexican patent number 9100290, 1996

Piñeyro-Lopez, A.; Martínez de Villarreal, L. \& González-Alanis, R. In vitro selective toxicity of toxin $\mathrm{T}-514$ from Karwinskia humboldtiana (buckthorn) plant on various human tumor cell lines. Toxicology, 92:217-27, 1994.

Sepúlveda-Saavedra, J.; Bermúdez de Rocha, M. V.; Tamez-Rodríguez, V. A.; Ballesteros-Elizondo, R. G.; Moreno-Sepúlveda, M. \& Piñeyro-López, A. Quantitative analysis of liver peroxisomes in rats intoxicated with peroxisomicine-A1. Toxicol. Lett., 98(1-2):715,1998 .

Sepúlveda-Saavedra, J.; Van der Klei, I. J.; Keiser, I.; Piñeyro-López, A.; Harder W. \& Veenhuis M. Studies on the effect of toxin T 514 on the integrity of peroxisomes in methylotrophic yeasts. FEMS Microbiol. Letts., 91:207-12, 1992.

Soto-Domínguez. A., Ballesteros-Elizondo, R. G., Saucedo-Cárdenas, O., Piñeyro-López, A. and Sepúlveda-Saavedra, J. Peroxisomicine A1 causes apoptosis in liver, kidney and lung: biochemical and morphological evidence. Moll. Biol. Cell, 16(12):5465-901, 2005.

Tuve, S.; Chen, B. M.; Liu, Y.; Cheng, T. L.; Touré, P.; Sow, P. S.; Feng, Q.; Kiviat, N.; Strauss, R.; Ni, S.; Li, Z. Y.; Roffler, S. R. \& Lieber, A. Combination of tumor site-located CTL-associated antigen-4 blockade and systemic regulatory t-cell depletion induces tumordestructive immune responses. Cancer Res; 67:(12).5929-39, 2007.

Venable, J. H. \& Coggeshall, R. A simplified lead citrate stain for use in electron microscopy. J. Cell. Biol., 25:407-8, 1965.

Watson, M. L. Staining of tissue sections for electron microscopy with heavy metals. II. Applications of solutions containing lead and barium. J. Biophys. Biochem. Cytol., 4:727-30, 1958.

\section{Correspondence to:}

Dr. Julio Sepúlveda-Saavedra

Facultad de Medicina de la UANL

Departamento de Histología, AP 1563

Monterrey, N.L. 64400

MÉXICO

\section{E-mail: jusesaa@netscape.net}

Received: 19-08-2011

Accepted: 25-11-2011 